\title{
STUDY OF POWDER METALLURGY B-TI ALLOY PROCESSED THROUGH HIGH-PRESSURE TORSION
}

\author{
(C) A. Amigó ${ }^{\text {, C.R.M. Afonso }}{ }^{2}$, V. Stolyarov ${ }^{3}$, D.Gunderov ${ }^{4}$, V.Amigó ${ }^{1}$ \\ ${ }^{1}$ Universitat Politècnica de València, València, Spain \\ ${ }^{2}$ Universidade Federal de São Carlos, São Carlos, SP, Brasil \\ ${ }^{3}$ Mechanical Engineering Research Institute of RAS, Moscow, Russia \\ ${ }^{4}$ Institute of molecule and crystal physics RAS, Ufa, Russia \\ vlstol@mail.ru
}

\begin{abstract}
Ti- $\beta$ alloys have a low elastic modulus, relative good specific properties and high corrosion resistance to be used like biomaterials. Elements like $\mathrm{Nb}$, Ta or Mo are used to obtain beta alloys. These elements have a better biocompatibility but, due to their refractory nature, difficult to obtain alloys. Powder metallurgy (PM) allows process new Ti- $\beta$ alloys decreasing costs, but work with high element addition can involve some problems like lack of diffusion, grain growth or $\alpha$-Ti phase formation. One method to refine the microstructure and improve the mechanical properties is severe plastic deformation technique through High-Pressure Torsion (HPT).This work studies the application of HPT using 5 turns under 6GPa of pressure in Ti-Nb-Ta-Fe alloys obtained by powder metallurgy. The initial microstructure is mainly $\beta$-Ti phase with some $\alpha$-Ti phase in grain boundaries. The HPT process refines the microstructure and breaks the grain boundaries until few microns. An increase of hardness was obtained, but $2 \%$ porosity remains contained.
\end{abstract}

Keywords: powder metallurgy, Ti alloy, properties, severe plastic deformation.

\section{ИССЛЕДОВАНИЕ БЕТА ТИТАНОВОГО ПОРОШКОВОГО СПЛАВА, ДЕФОРМИРОВАННОГО КРУЧЕНИЕМ ПОД ВЫСОКИМ ДАВЛЕНИЕМ}

Аннотация. Бета титановые сплавы обладают низким модулем упругости, относительно хорочими удельной прочностью и коррозионной стойкостью для применения в качестве биоматериалов. Для легирования сплава обычно используют ниобий, тантал и молибден. Эти элементы имеют высокую биосовместимость, но из-за высокой температуры плавления их трудно вводить в сплав. Метод порошковой металлургии позволяет уменьшить стоимость прочесса, но большое количество добавок может затруднить диффузию, вызвать рост зерен или появление альфа титана. Одним из методов измельчения микроструктуры и улучшения механических свойств является интенсивная пластическая деформация, выполняемая кручением под давлением. В этой работе исследуется данный метод при давлении 5 ГПа и 5 оборотов в порошковом сплаве Ti-Nb-Ta$F e$. Исходная структура в основном является бета фазой с небольшим количеством альфа титана на границах зерен. Метод интенсивной деформации приводит измельчению зерен до нескольких микрон, увеличению микротвердости и уменьшению пористости до 2\%.

Ключевые слова: порошковая металлургия, титановый сплав, свойства, интенсивная пластическая деформачия

Acknowledgement. The authors would like to thank Universitat Politècnica de València (UPV) for the financial support by Researcher Training Program, Spanish Ministry of Economy and Competitiveness under the Research Project MAT2014-53764-C3-1-R, European Commission due to FEDER founds to acquire investigation equipment, Electron Microscopy Service of the Universitat Politècnica de Valencia (UPV), Spain and "Laboratório de Caracterização Estrutural" (LCE) of DEMa-UFSCar, Brazil. 
Introduction. Titanium alloys have been used in a variety of medical applications due to their excellent biocompatibility, osteosynthesis, corrosion resistance and mechanical behavior [1-2]. The commercial Ti alloy widely used is Ti-6Al-4V due to their bigger interest for other sectors industry. However, it has been reported to be potentially toxic due to the $\mathrm{Al}$ and $\mathrm{V}$ ion release and therefore may cause some clinical problems [3-4]. In an attempt to avoid this, more biocompatible elements can be used. However the effort in recent years has focused on the development of new $\beta$-type Ti alloys using biocompatible elements such as $\mathrm{Nb}, \mathrm{Mo}, \mathrm{Ta}$ or $\mathrm{Zr}$ [5]. The interest in $\beta$-Ti alloys as biomaterials was derived from the excellent combination of a high mechanical resistance with low elastic modulus (E) [6]. When $\mathrm{Nb}$ content is between 20 to $50 \mathrm{wt} \%$ the alloys show an elastic modulus around $60 \mathrm{GPa}$ [7] in front of $110 \mathrm{GPa}$ of Ti-6Al-4V alloy [4]. This kind of elements have a refractory character that hinder the diffusion in Ti during the sintering. Other $\beta$-stabilizer elements are the eutectoid type: $\mathrm{Fe}, \mathrm{Cr}$, Co or $\mathrm{Mn}$ [8]. These elements present a stronger effect in $\beta$-Ti phase stabilization, therefore have less biocompatibility. Addition of small amounts of Fe improves the $\beta$ phase stability, without sacrificing biochemical suitability of Ti alloys [9-11]. The manufacture process of $\beta$-Ti alloy is expensive; powder metallurgy can provide a good process technology to create customized alloys, although it has its own limitations as well as lack of diffusion, porosity or grain growth [12]. The use of powder metallurgy to obtain these $\beta$-type Ti alloys was previously studied by other authors, using uniaxial pressure [13], hydride powders [14] or high densification techniques [15].

High pressure torsion (HPT) is one of metalworking techniques involving very large strains. In crystalline materials it results in formation nanocrystalline (NC) structure $(\mathrm{d}<100 \mathrm{~nm})[16]$; V.V. Stolyarov and R.Z. Valiev, Bulk Nanostructured Metastable Alloys Prepared by Severe Plastic Deformation, Journal of Metastable and Nanocrystalline Materials, V 1 (1999) 185-190] [17] However HPT processing to powder metallurgy $\beta$-Ti alloys untill now has not been used.

The main objective of this work is study the effect of High-Pressure Torsion (HPT) process Ti35Nb10Ta3Fe in weight percentage.

Materials and methods. Powder metallurgy processing of elemental blend powders was used in order to obtain the alloys. Nominal compositions studied in this work are: Ti35Nb10Ta and Ti35Nb10Ta3Fe (wt.\%). Commercial pure metal powders were supplied by Atlantic Equipment Engineers with high purity and different sizes: $\mathrm{Ti}$ ( $99.7 \%$ of purity and $55 \mu \mathrm{m}$ of average size), $\mathrm{Nb}$ (99.8\%, $20 \mu \mathrm{m})$, Ta $(99.8 \%, 8 \mu \mathrm{m})$ and $\mathrm{Fe}(99.9 \%, 34 \mu \mathrm{m})$.

Compaction was made in floating die of $20 \mathrm{~mm}$ of diameter, Hydraulic press of $500 \mathrm{kN}$ (INSTRON model 1343) was used applying $600 \mathrm{MPa}$ of uniaxial pressure. Sintering was performed at $1250^{\circ} \mathrm{C}$ and $1300^{\circ} \mathrm{C}$, during 3 hours in a high vacuum tubular furnace (Carbolite model 15-75-450). Cooling was performed in the furnace. The samples for HPT had an initial thickness of $1 \mathrm{~mm}$. HPT test was performed using $6 \mathrm{GPa}$ of pressure and 5 turns. The sample diameter was $20 \mathrm{~mm}$.

For HPT processing, the sample was located between two anvils that apply a compressive pressure of $6 \mathrm{GPa}$ and simultaneously produce a torsional strain. To estimate the strain different authors use alternative relationships, assuming that thickness of disk is independent to rotation angle or incorporating the decrease of thickness with the pressure [17] showing near a $20 \%$ of difference between the different conditions. Valiev et al. [16] use the following equation.

$$
\mathrm{e}=\ln (\mathrm{r} \theta / \mathrm{h})
$$

Where $\theta$ is the rotation, $r$ is radius of sample, $h$ is thickness. Using (1) to calculate the true strain for 5 whole revolutions, results in 7.1 of true strain.

To perform the mechanical and microstructural characterization, two positions on the sample were selected. One with higher true strain, calculated for $\mathrm{r}=10 \mathrm{~mm}$, and the other one with a medium value, calculated for $\mathrm{r} / 2=5 \mathrm{~mm}$. To perform the microstructural characterization, samples were 
grinded step by step and polished using $9 \mu \mathrm{m}$ diamond suspension and colloidal silica as finishing step. Phase identification was studied using X-Ray diffraction (XRD) (Bruker D2 Phaser). The microstructure characterization of samples was performed with field emission (FEG) scanning electron microscope (SEM, Zeiss Ultra 55) using backscattering electrons (BSE) to reveal microstructure and obtain grain size measurements by analysis image. Additionally, selected specimens were investigated by (scanning) transmission electron microscopy (TEM/STEM) through a FEI Tecnai F20 G2 at $200 \mathrm{kV}$ and field emission gun (FEG) with EDS detector EDAX. Mechanical characterization was performed by nanoindentation (MTS Nano 200G) using CSM mode with deep control, indenting $1600 \mu \mathrm{m}$ of depth. The Poisson's ratio is required to calculate the values of hardness and elastic modulus by nanoindentation. This value was obtained by ultrasonic test (Karl Deutsch digital Echograph) on initial powder metallurgy samples. Before HPT process the porosity and the density was obtained by Archimedes test according to the standard UNE EN ISO 2738.

Results. The samples of Ti35Nb10Ta(3Fe) alloys obtained through PM present mainly $\beta$-Ti (bcc) grains in $\mathrm{Nb}$-rich zones and a reduced fraction of $\alpha+\beta$ regions with $\alpha$ phase laths in $\mathrm{Nb}$-poor zones, according to results of XRD (Fig. 1) and microstructure characterization. The microstructure of PM samples can be observed in Figure 2, where SEM micrographs in BSE mode of Ti35Nb10Ta alloy, sintered at $1250^{\circ} \mathrm{C}$ (Fig. 2.a) shows some $\mathrm{Nb}$ particles (due to lack of diffusion) surrounded by $\mathrm{Nb}$ rich zones and $\alpha+\beta$ regions with precipitation of $\alpha$ phase laths in $\mathrm{Nb}$-poor zones and $1300^{\circ} \mathrm{C}$ (Fig. 2.b) with reduced fraction of $\mathrm{Nb}$ particles, due to higher temperature imposed and more uniform $\beta$ Ti phase grains. Similar behavior is observed for the alloy with Fe addition Ti35Nb10Ta3Fe.



Figure 1. XRD for PM Ti35Nb10TaxFe $(x=0,1.5,3.0$ and $4.5 \mathrm{wt} \% \mathrm{Fe})$ alloys sintered at $1250^{\circ} \mathrm{C}$.

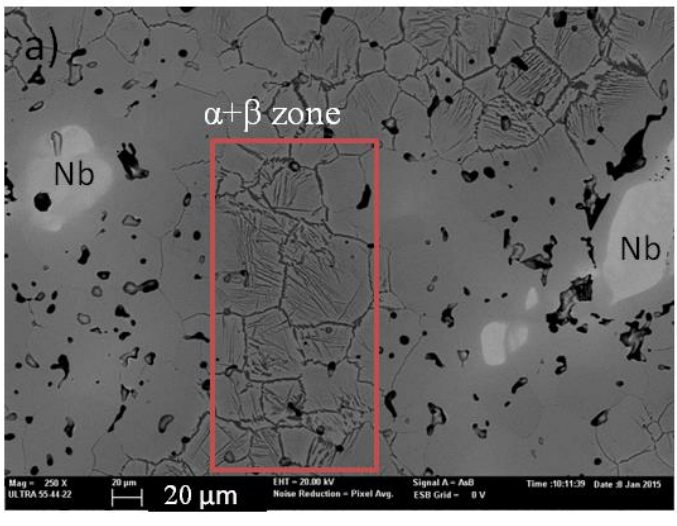

a



6

Figure 2. SEM images in BSE mode of PM Ti35Nb10 Ta alloy sintered at a) $1250^{\circ} \mathrm{C}$ and b) $1300^{\circ} \mathrm{C}$ 
Table 1 shows results of grain size and porosity (\%) measurements through image analysis for powder metallurgy $\mathrm{PM} \mathrm{Ti} 35 \mathrm{Nb} 10 \mathrm{Ta}(3 \mathrm{Fe})$ samples. The addition of $3 \% \mathrm{Fe}$ to $\mathrm{Ti} 35 \mathrm{Nb} 10 \mathrm{Ta}$ alloy leads to grain growth of $33 \%$ and $38 \%$ for sintering temperatures of $1250^{\circ} \mathrm{C}(45$ to $60 \mu \mathrm{m}) 1300^{\circ} \mathrm{C}$ (50 to $69 \mu \mathrm{m}$ ), respectively.

Table 1. Grain size and porosity (\%) for powder metallurgy PM Ti35Nb10TaxFe samples.

\begin{tabular}{ccccc}
\hline \multirow{2}{*}{ Samples } & \multicolumn{2}{c}{ Grain size $(\mu \mathrm{m})$} & \multicolumn{2}{c}{ Porosity \% } \\
& $1250^{\circ} \mathrm{C}$ & $1300^{\circ} \mathrm{C}$ & $1250^{\circ} \mathrm{C}$ & $1300^{\circ} \mathrm{C}$ \\
\hline Ti35Nb10Ta & $45 \pm 2$ & $50 \pm 2$ & $5.1 \pm 0.6$ & $4.2 \pm 0.1$ \\
Ti35Nb10Ta3Fe & $60 \pm 2$ & $69 \pm 4$ & $9.2 \pm 0.3$ & $8.3 \pm 0.2$ \\
\hline
\end{tabular}

Regarding the porosity, $3 \% \mathrm{Fe}$ addition increased the volume fraction of pores $(\% \mathrm{P})$ significantly, reaching almost double of porosity for sintering temperature of $1300^{\circ} \mathrm{C}(\% \mathrm{P}=4.2$ to $8.3 \%)$ and $80 \%$ more pores for $1250^{\circ} \mathrm{C}(\% \mathrm{P}=5.1$ to $9.2 \%)$. The effect of $\mathrm{Fe}$ on porosity depends on the size of initial powder used [1], due to the stronger $\beta$-stabilization effect of Fe addition. The increment of sintering temperature (from 1250 to $1300^{\circ} \mathrm{C}$ ) confirmed a decreasing of $17 \%$ and $10 \%$ of porosity for Ti35Nb10Ta and Ti35Nb10Te3Fe alloys, respectively.

Samples obtained by $\mathrm{PM}$ of $\mathrm{Ti} 35 \mathrm{Nb} 10 \mathrm{Ta}(3 \mathrm{Fe})$ alloys were submitted to severe plastic deformation through high pressure torsion (HPT). The SEM micrographs in Figure 3 show the microstructure of nanoscale $\beta$-Ti alloys with variations in composition and $\mathrm{Nb}$-rich regions (light gray) left during PM processing due lack of diffusion. Figure 3.a illustrates SEM image in BSE of HPT for Ti35Nb10Ta3 Ta alloy sintered at $1250^{\circ} \mathrm{C}$ and reveals the plastic deformation flux lines and more pronounced variation of composition of $\mathrm{Nb}$. Darker regions seems to be blocky $\alpha$-Ti particles and moreover all of porosity disappears during HPT processing, as can be confirmed in Fig. 3.b for Ti35 Nb10Ta3 Ta alloy sintered at $1300^{\circ} \mathrm{C}$, and in Fig. 3.a as well. Higher sintering temperature of $1300^{\circ} \mathrm{C}$ leads to a more uniform microstructure of HPT sample resulting in less pronounced variation of $\mathrm{Nb}$ trough deformation lines.
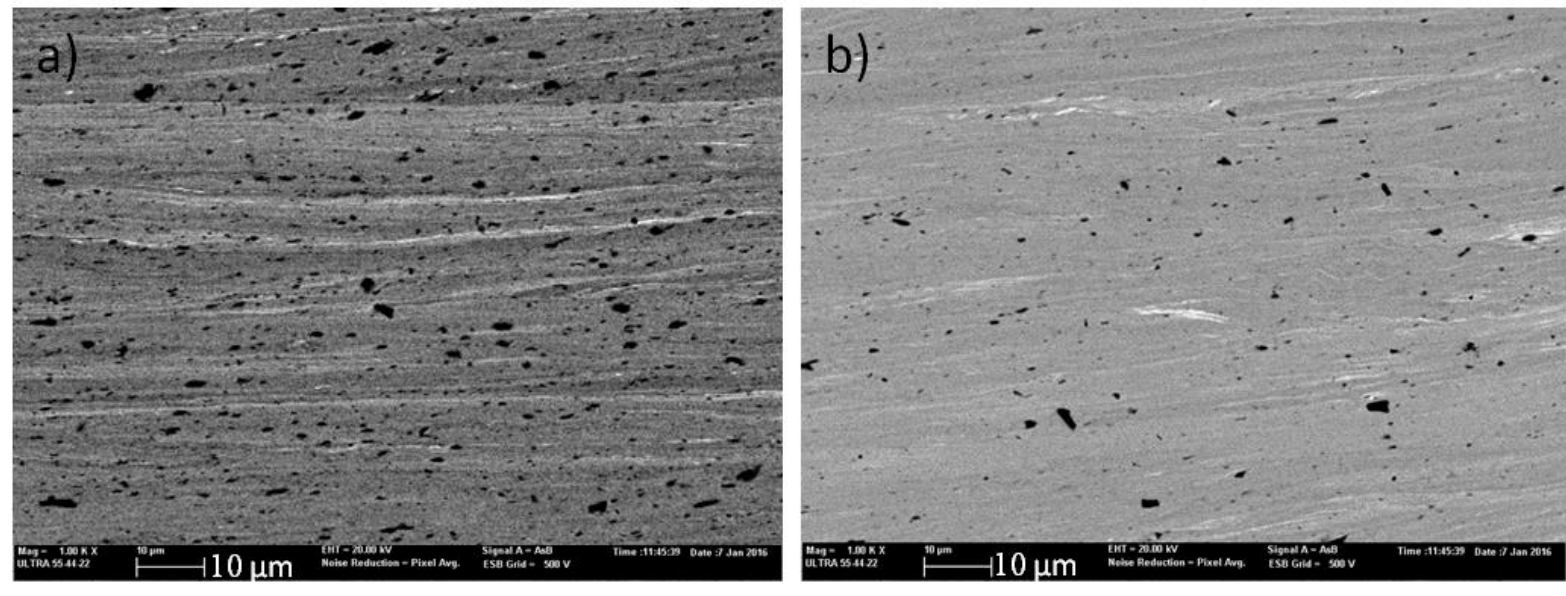

Figure 3. SEM images in BSE of HPT Ti35Nb10Ta3Ta alloy sintered at a) $1250^{\circ} \mathrm{C}$ and b) $1300^{\circ} \mathrm{C}$

TEM analysis confirms the presence of metastable $\omega$-Ti phase in PM samples before HPT process of Ti35Nb10Ta alloy sintered at $1250^{\circ} \mathrm{C}$ (Figure 3.a). Select area diffraction pattern (SADP) performed in $\beta$ - $\mathrm{Ti}$ ( $\mathrm{Nb}$-rich region) in white dotted square is showed in Figure 3.a (upper right corner inset), with [113 $]_{\beta}$ zone axis and double diffraction of metastable $\omega$ phase spots. After HPT processing of PM sample, it is possible to confirm through TEM image (Fig. 3.b) the presence of nanometric grain size of $\beta$-Ti35Nb10Ta alloy obtained by severe plastic deformation. 
TEM micrograph of PM sample in Fig. 4.a shows the presence of $\beta$-Ti, $\alpha$-Ti laths and metastable nanometric $\omega$ inside a $\beta$ phase grain. On the other hand, HPT sample micrograph confirms the reduction of grain size due to near ring shape selected area diffraction pattern, SAPD (figure 4, c). Such high deformations imposed by HPT reduce significantly the grain size in $\beta$-Ti phase, going from 45 microns to tens of nanometers after processing. Moreover, $\alpha$-Ti phase (harder) showed lower grain size reduction than $\beta$-Ti soft matrix due to the differences of mechanical strength between phases.

Although the x-ray diffraction (XRD) patterns shows only $\alpha$-Ti and $\beta$-Ti phases, without clear peaks of metastable $\omega$ phase, the TEM analysis coupled to EDS analysis shows that a variation in $\mathrm{Nb}$ content in the range of 27 to $35 \mathrm{wt} \% \mathrm{Nb}$ (and other alloying elements $\mathrm{Ta}$ and $\mathrm{Fe}$ ) can present some metastable $\omega$ phase precipitation. Some works in the literature indicate that formation of metastable $\omega$ phase can be favored by lower cooling rates from the $\beta$ phase field and similar compositions [19].

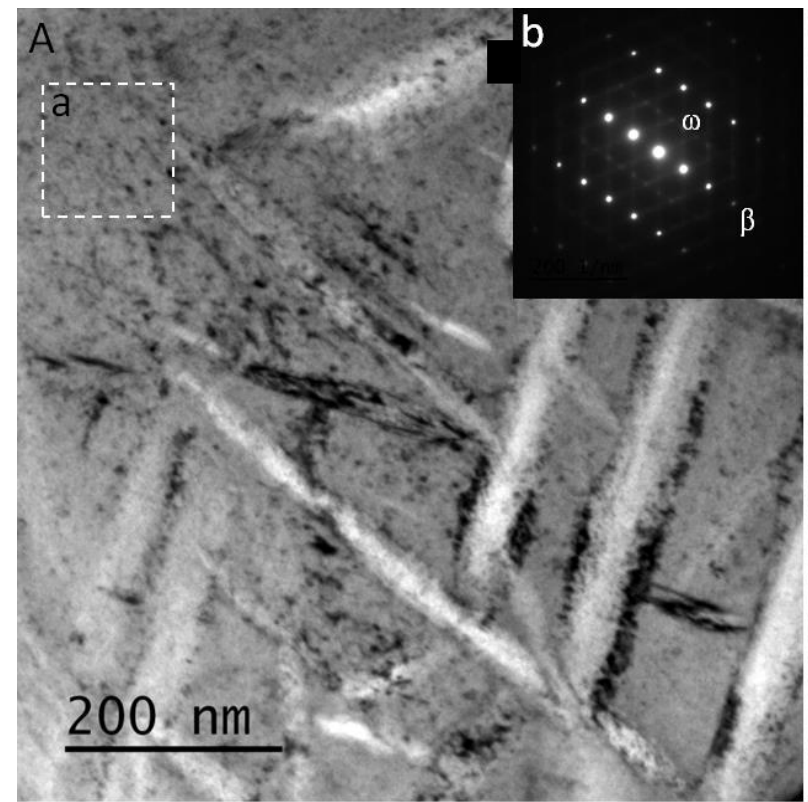

a

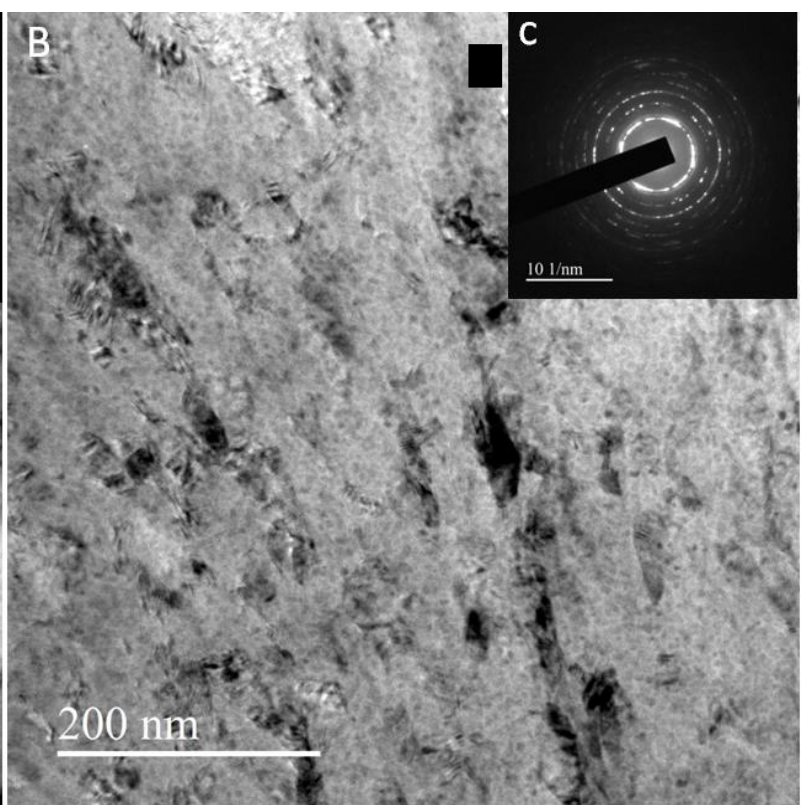

6

Figure 4. TEM image of Ti35Nb10Ta sintered at $1250^{\circ} \mathrm{C}$. a) PM and respective SADP of $\beta$-Ti rich region in zone axis $[113]_{\beta}$ and double diffraction spots of $\omega$ phase, $b$ ) nanostructure of HPT sample with 5 turns under $6 \mathrm{GPa}$ on a transversal section in $\mathrm{R} / 2$ with nanometric $\beta$-Ti phase grains after HPT processing together with respective SADP showing spots $\left(\mathrm{d}_{\mathrm{hkl}}\right)$ of $\beta$-Ti and $\omega$ phases in the ring shaped SADP pattern.

Elastic modulus obtained by nanoindentation test showed an increasing of $19 \%$ with Fe addition (82 to $98 \mathrm{GPa}$ ) in PM samples, according to Table 2, and that results is in agreement with other authors that show an increment of modulus in Ti-Nb alloys due to small additions of Fe [20]. On the other hand, results shown in Table 2, present a variation with Fe addition of $16 \%$ when test was performed in $\alpha+\beta$ regions for PM samples and in the same way for HPT cases. This can be related to the mixture of phases in a nanometric microstructure, justifying the variation of elastic modulus from $\beta$ to $\alpha+\beta$ regions. A variation of $5 \%$ was observed in regions with different true strength on the same HPT sample. The difference between these regions was about 6.4 for $r / 2$ and 7.1 for $r$ when true strength was calculated using equation 1 . 
Table 2. Hardness and Elastic Modulus (GPa), obtained by nanoindentation test, for PM samples study the differentiated zones indicated in figure 1.

\begin{tabular}{|c|c|c|c|c|c|c|}
\hline \multirow{2}{*}{$\begin{array}{c}\text { Hardness }(\mathrm{GPa}) \\
\text { composition }\end{array}$} & \multicolumn{2}{|c|}{$\mathrm{PM}$ alloys $\left(1250^{\circ} \mathrm{C}\right)$} & \multicolumn{2}{|c|}{ HPT $\left(1250^{\circ} \mathrm{C}\right)$} & \multicolumn{2}{|c|}{ HPT $\left(1300^{\circ} \mathrm{C}\right)$} \\
\hline & $\beta$ & $\alpha+\beta$ zone & $\mathrm{R} / 2$ & $\mathrm{R}$ & $\mathrm{R} / 2$ & $\mathrm{R}$ \\
\hline Ti35Nb10Ta & $3.7 \pm 0.6$ & $4.2 \pm 0.6$ & 5 . & $4.8 \pm$ & $5.0 \pm 0.1$ & $5.1 \pm 0.1$ \\
\hline Ti35Nb10Ta3Fe & $3.3 \pm 0.3$ & $5.2 \pm 0.5$ & $6.1 \pm($ & $6.1 \pm$ & $6.4 \pm 0.2$ & $6.5 \pm 0.1$ \\
\hline $\mathrm{E}(\mathrm{C}$ & \multicolumn{2}{|c|}{ PM alloys $\left(1250^{\circ} \mathrm{C}\right)$} & \multicolumn{2}{|c|}{ HPT $\left(1250^{\circ} \mathrm{C}\right)$} & \multicolumn{2}{|c|}{ HPT $\left(1300^{\circ} \mathrm{C}\right)$} \\
\hline composition & $\beta$ & $\alpha+\beta$ zone & $\mathrm{R} / 2$ & $\mathrm{R}$ & $\mathrm{R} / 2$ & $\mathrm{R}$ \\
\hline Ti35Nb10Ta & $82 \pm 8$ & $91 \pm 6$ & $84 \pm 2$ & $79 \pm 2$ & $84 \pm 1$ & $84 \pm 1$ \\
\hline Ti35Nb10Ta3Fe & $98 \pm 3$ & $106 \pm 6$ & $84 \pm 1$ & $92 \pm 1$ & $99 \pm 2$ & $98 \pm 1$ \\
\hline
\end{tabular}

Values of nanoindentation hardness increased from 3.7 and $3.3 \mathrm{GPa}$ for PM samples of Ti35Nb10Ta and Ti35Nb10Ta3Fe alloys, respectively, to around 5.0 up to $6.5 \mathrm{GPa}$ for HPT samples of same alloys, respectively. Elastic modulus obtained by nanoindentation just varied significantly from PM sample of Ti35Nb10Ta3Fe alloy (98 GPa) down to $84 \mathrm{GPa}$ for HPT sample $\left(1250^{\circ} \mathrm{C}\right)$ at $\mathrm{r} / 2$.

Figure 5 clarifies the higher influence, on hardness variation, of Fe contents in the alloy than the sintering temperature. Moreover the variation induced HPT process due to the transformation on microstructure.



Figure 5 Graphic of hardness and elastic modulus (GPa), obtained by nanoindentation test, for PM samples $\left(1250^{\circ} \mathrm{C}\right)$ in the different zones indicated in Figure 1, and HPT samples in radial distances $(\mathrm{R}$ and $\mathrm{R} / 2)$ and different $\mathrm{PM}$ sintering temperature precursors.

Conclusions. The study performed in this work presents the following conclusions:

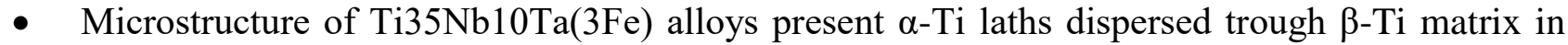
regions with lower amount of $\beta$-stabilizers $(\mathrm{Nb}$, Ta y $\mathrm{Fe})(27 \mathrm{wt} \% \mathrm{Nb})$, and stable $\beta$-Ti phase in regions rich in $\beta$-stabilizers $(35 \mathrm{wt} \% \mathrm{Nb})$. TEM analysis confirmed precipitation of metastable $\omega$ phase, and the higher stability of $\beta$-Ti phase, the lower the fraction of omega. 
- Beta phase stabilization increases with $\mathrm{Fe}$ addition and sintering temperature for Ti35Nb10Ta $(3 \mathrm{Fe})$ alloys, and the subsequent HPT process applied on PM samples leads to nanostructure without porosity.

- Nanoindentation hardness of Ti35Nb10Ta(3Fe) improves with severe plastic deformation, and it is influenced more significantly by $\mathrm{Fe}$ addition than by sintering temperature variation.

- The application of HPT process leads to nanocrystalline structure $\beta$-Ti phase, besides that it homogenizes the elastic modulus obtaining low values similar to that of $\beta$-Ti alloys in PM samples $(78-83 \mathrm{GPa})$. The Fe addition to Ti35Nb10Ta increases elastic modulus around 15 $\mathrm{GPa}$ in all instances.

\section{References}

[1] R. Strietzel, A. Hosch, H. Kalbfleisch, D. Buch. In vitro corrosion of titanium// Biomaterials.19 (1998). - P. 1495-1499.

[2] M. Koike, H. Fuji. The corrosion resistance of pure titanium in organic acids// Biomaterials.22 (2001). - P. 2931-2936.

[3] W. Österle, D. Klaffke, M. Griepentrog, U. Gross, I. Kranz, Ch. Knabe. Potential of wear resistant coatings on Ti-6Al-4V for artificial hip joint bearing surfaces// Wear. - 264 (2008). P. 505-517.

[4] Y. Li, Ch. Yang, H. Zhao, S. Qu, X. Li, Y. Li. New developments of Ti-Based alloys for biomedical applications// Materials. - 7 (2014). - P. 1709-1800.

[5] M. Geetha, A.K. Singh, R. Asokamani, A.K. Gogia. Ti based biomaterials. the ultimate choice for orthopaedic implants // A review. Progress in Materials Science. - 54 (2009). - P. 397-425.

[6] M. Bönisch, M. Calin, T. Waitz, A. Panigrahi, M. Zehetbauer, A. Gebert, W. Skrotzki, J. Eckert. Thermal stability and phase transformations of martensitic Ti-Nb alloys// Sci. Technol. Adv. Mater. - 14 (2013), 055004. - (9 pp).

[7] A. Cremasco, W.R.Osório, C.M.A. Freire, A. Garcia, R. Caram. Electrochemical corrosion behavior of a Ti-35Nb alloy for medical prostheses// Electrochim. Acta. - 53 (2008). - P. 48674874.

[8] R. Boyer, E.W. Collings, G. Welsch. Materials properties handbook: Titanium alloys. - ASM International. Ohio. EE.UU. - 1994. - P. 9-11.

[9] I. Kopova, J. Stráský, P. Harcuba, M. Landa, M. Janeček, L. Bačákova. Newly developed Ti$\mathrm{Nb}-\mathrm{Zr}-\mathrm{Ta}-\mathrm{Si}-\mathrm{Fe}$ biomedical beta titanium alloys with increased strength and enhanced biocompatibility// Mat. Sci. and Eng. C. - 60 (2016). - P. 230.

[10]P. Xue, Y. Li, K. Li, D. Zhang, Ch. Zhou. Superelasticity, corrosion resistance and biocompatibility of the Ti-19Zr-10Nb-1Fe alloy// Mat. Sci. and Eng. C. - 50 (2015). - P.179186.

[11]A. Biesiekierski, J. Lin, Y. Li, D. Ping, Y. Yamabe-Mitarai, C. Wen. Investigations into Ti(Nb,Ta)-Fe alloys for biomedical applications// Acta Biomater. - 32 (2016). - P. 336-347.

[12] J. Teixeira, B. Appolaire, E. Aeby-Gautier, S. Denis, F. Bruneseaux. Modeling of the effect of the beta phase deformation on the alpha phase precipitation in near-beta titanium// Acta Mater. 54. - 16 (2006). - P. 4261-4271.

[13] K.A. Nazari, A. Nouri, T. Hilditch. Mechanical properties and microstructure of powder metallurgy Ti-xNb-yMo alloys for implant materials// Mater. Des. - 88 (2015). - P. 11641174.

[14]M.W.D. Mendes, C.G. Ágreda, A.H.A. Bressiani, J.C. Bressiani. A new titanium based alloy $\mathrm{Ti}-27 \mathrm{Nb}-13 \mathrm{Zr}$ produced by powder metallurgy with biomimetic coating for use as a biomaterial// Mat. Sci. and Eng. - C 63 (2016). - P. 671-677. 
[15] B. Sharma, S.K. Vajpa, K. Ameyama. Microstructure and properties of beta Ti-Nb alloy prepared by powder metallurgy route using titanium hydride powder// J Alloys Compd. - 656 (2016). - P. 978-986.

[16]R. Z. Valiev, R. K. Islamgaliev and I. V. Alexandrov. Bulk Nanostructured Materials from Severe Plastic Deformation// Progress in Materials Science. - 2000. - Vol 45. - P. 103-189.

[17] V.V. Stolyarov and R.Z. Valiev, Bulk Nanostructured Metastable Alloys Prepared by Severe Plastic Deformation// Journal of Metastable and Nanocrystalline Materials. - V 1 (1999). - P. 185-190.

[18] J. O'Flynn, S.F. Corbin. The influence of iron powder size on pore formation, densification and homogenization during blended elemental sintering of Ti-2.5Fe// J Alloys Compd. - 618 (2015). - P. 437-448.

[19] S.A. Souza, R.B. Manicardi, P.L. Ferrandini, C.R.M. Afonso, A.J.R. Londoño, R. Caram. Effect of the addition of $\mathrm{Ta}$ on microstructure and properties of $\mathrm{Ti}-\mathrm{Nb}$ alloys// Journal of Alloys and Compounds. - 504 (2010). - P. 330-340.

[20]D.C. Zhang, Y.F. Mao, Y.L. Li, J.J. Li, M. Yuan and J.G. Lin. Effect of ternary alloying elements on microstructure and superelastictity of Ti-Nb alloys// Mat. Sci. and Eng. A. - 559 (2013). - P. 706-710.

Дата поступления: 31 марта 2018 г. 